\title{
The Integration Analysis Research of Colleges and Universities: Innovation Entrepreneurship Education and Professional Education
}

\author{
Yanqiu Liang \\ College of Normal, Nanyang Institute of Technology, Nanyang, Henan, China
}

Keywords: Colleges and Universities, Innovation entrepreneurship education, Professional education, Integration.

\begin{abstract}
As China's population increasing, the employment pressure is becoming more and more big, for college students graduating towards society, their skill level and comprehensive quality remains to be strengthened, especially to the entrepreneurial university students, colleges and universities should be timely to fulfill business education for students, so as to promote the university students' employment, in order to alleviate employment pressure. Innovative entrepreneurship education and professional education in colleges and universities are presented in this paper the practice of the integration of research, scientific and reasonable Suggestions were put forward.
\end{abstract}

\section{Introduction}

In China's colleges and universities in recent years, talent training, and meet the demand of social and economic development are still far away, especially the lack of innovative talents and innovative entrepreneurial ability drop, etc. , have become the main factors which restrict the development of the Chinese universities. In order to be able to further improve China's college students' innovative ability and consciousness, in terms of innovative entrepreneurship education need to be strengthened, the construction of scientific and rational innovation entrepreneurship education base, deliver more innovative talents for the society.

\section{The significance of China's innovation in colleges and universities entrepreneurship education}

Innovation entrepreneurship education and academic education, vocational education has become the main purpose of university education in China, the connotation of innovative entrepreneurship education as the "innovative, creative and pioneering", not to need to make the students obtain knowledge skills in the short term, to complete the learning task, but the need of students' skills in learning knowledge at the same time, apply the theoretical knowledge in creative practice, in order to cultivate the students' creative consciousness and ability, the following is the significance of university creative education.

\subsection{Build an innovative country.}

In China in 2005 for the first time put forward the idea of building an innovative country, the former Chinese President Hu Jintao in 2012 national conference on science and technology put forward "to the 2020 China needs to realize the goal of cultivating innovative talents, optimize the environment of innovation, improve the scientific quality, into an innovative country team goal. ", and in 2012 the party's 18th conference has clearly put forward to implement the strategy of innovation driven countries, this means that China needs to put science and technology innovation in China's development of the primary position [1]. Essence lies in the development of science and technology to build an innovation-oriented country strategy simply positioned to enhance China's capacity for independent innovation, the innovation path of socialism with Chinese characteristics, at the same time to build an innovation-oriented country, you will need to continuously strengthen the innovation of the entrepreneurial education practice, in order to train more innovative talents [2]. Innovation in colleges and universities entrepreneurship education needs innovation in combination 
with the theory and practice of entrepreneurship education, in order to help students form creative consciousness, as a result, not only can stimulate more students to participate in the activities of national innovative undertaking construction actively, also can improve the university students' innovative undertaking ability and quality.

\subsection{Help to cultivate creative talents.}

In order to be able to further complete the purpose of building an innovative country in China, China needs to train more innovative, flexible, good at communication advantages of innovative talents, but because China is now the talent distribution is not balanced, especially the reform of college teaching implementation cannot reach the designated position, make the talent training plan can't really get implementation, students' professional skill cannot ascend, nature also won't have the basic competitiveness of employment [3]. Therefore, creative education of colleges and universities should actively guide students actively participate in the campus creative education activities, to help students have a thorough understanding of its subject characteristics and advantages, and combined with innovative technology, in this way, can make students quickly adapt to the social life and work, also be helpful for the adjustment of Chinese society human resources and configuration.

\subsection{Creative thinking improvement.}

Innovation in colleges and universities entrepreneurship education fundamental purpose is to cultivate students' creative thinking, and found the problem, ask questions, problem solving skills, make students to have the enterprising spirit of the creative talents. Innovative entrepreneurship education training of students should be able to independently in the face of the world and the future development of modernization, but the need to constantly improve students' comprehensive quality and practical ability to achieve [2]. In addition, now gathered speed development of economic globalization, market competition is fierce, and the essence of market competition has turned to for science and technology competition, competition of science and technology can directly embodied in talent competition among all countries. Thus, in order to further improve China's comprehensive national strength, cultivate entrepreneurial ability, high comprehensive qualities of innovative talents, need to speed the perfect innovation entrepreneurship education practice work, so as to deliver more innovative talents for China.

\section{The integration of innovation in colleges and universities entrepreneurship education and professional education}

\subsection{Establish creative teachers.}

Management institution innovation in colleges and universities entrepreneurship education practice to more formal planning innovation entrepreneurship education, some colleges and universities should be conditional among innovation entrepreneurship education practice management institution, establish innovative entrepreneurship education research or research department. Now China's innovation in colleges and universities entrepreneurship education has not been mature theoretical system, from the perspectives of theory innovation entrepreneurship education problems, the law of development, innovation, entrepreneurial experience, etc. , thus more need for innovation entrepreneurship education theory to study [3]. In terms of teaching practice, teachers of colleges and universities to carry out the creative education are mostly comes from the enterprise management science teachers, lack of experience and experience will be greatly, its theoretical knowledge more practical experience, cannot satisfy the requirement of the creative education practice. Thus, in order to be able to meet the practical demand for the innovation of colleges and universities entrepreneurship education, the need to cultivate a group of as soon as possible with practical experience, obtains the qualification of teachers to participate in the innovation entrepreneurship education practice teaching in colleges and universities. In addition, the innovation of colleges and universities entrepreneurship education the establishment of laboratories, is conducive to innovation in colleges and universities entrepreneurship education theory research, 
and can greatly improve the level of creative education teaching in colleges.

\subsection{Strengthen teachers' innovative pioneering consciousness.}

When innovation in colleges and universities entrepreneurship education research department set up complete, need timely to strengthen teachers' creative consciousness, especially teachers for innovation entrepreneurship education guide and executives, creative quality and level of education depends on teachers' comprehensive quality and teaching ability, the innovation entrepreneurship education in colleges and universities should organize regular teachers participate in lectures, training, etc. , such as Shanghai Jiao tong university held three shift exchange activities, can be very good to improve teachers' teaching level [4]. Nowadays, colleges and universities has become the core part of the scientific research work in China, but its scientific and technological achievements conversion rate is low, mainly because the lack of innovation entrepreneurship education in colleges and universities, if university scientific research projects in research and development in the research of innovative entrepreneurship education in the process of thought, you can closely linked together with social production reality, natural science and technology achievements conversion rate can be improved, too. At the same time, in order to ensure the quality of creative education teaching, to ensure the effectiveness of the college students' innovative entrepreneurial education practice, teachers need to organize into the society and enterprises, through direct contact with social enterprises, to further improve the teaching quality.

\subsection{Combined with professional practice teaching.}

To lay a foundation of innovative undertaking and you will need to increase the students' innovative thinking and innovative ability training, for students to develop targeted strong innovative talent training plan, establish the perfect creative talents training system, but it needs to be professional practice teaching as the key. Entrepreneurship is the essence of innovation and change, for entrepreneurs, only innovation of entrepreneurship is not enough, there is no innovation also hard to entrepreneurship, innovation need to master the professional theoretical knowledge and practical skills, professional practice teaching is to help students get more theory knowledge, the main way to improve students' practice ability [4]. Professional practice teaching contents will often professional talent employment, entrepreneurship needs to combine, can according to the requirements of the specific professional knowledge and the ability to innovative entrepreneurial knowledge and ability training is blended in among them, and can according to these requirements in order to develop the corresponding innovative undertaking teaching practice [5]. In addition, in the professional practice teaching course, can timely tracking industry trends, grasp the direction of professional learning, curriculum setting and practice teaching science unifies in together, ensure that students can use you have to master the knowledge and skills to implement innovative entrepreneurial talent training goal.

\subsection{Raise the level of creative teaching.}

To improve the level of creative teaching, you will need to type the project practice teaching model innovation entrepreneurship as the core, let every student can get innovative thinking and innovative consciousness. Project practice teaching are the main task is to complete the project as the goal, for the integrated use of students' professional knowledge and skills, knowledge and practical training, to cultivate students' scientific research ability, creative thinking ability [5]. At the same time, the practice can reflect student's main body characteristics of the project type, students can independently to complete the project plan for discussion, equipment preparation, project plan execution, all links. Once students as the main body of the project practice, the teachers should transform their roles in time, give full play to their guiding role, atmosphere for the students to create more innovative research learning environment, so that can increase the confidence of students' innovative entrepreneurial. In addition, the teacher can hold some entrepreneurial projects, to help students to improve their communication ability, organization ability, innovation ability and competition ability.

\subsection{Strengthen the innovation ability training.}

Chinese university students' entrepreneurship desire so intense, but is not high, the proportion of 
actual participation in entrepreneurial business success rate is low, the main reason is that of some of the practical activities and social projects in colleges and universities there exists a large gap, students without actual social work experience has been involved in a startup, nature also can appear a lot of problems. According to this problem, colleges and universities can let the student in the graduation practice stage unit to participate in the work of labor in society, to help students to accumulate work experience, so that the students for their professional understanding really walk into society to lay a solid foundation for the future [6]. At the same time, colleges and universities in recent years, often let students directly through personal contact and select graduation time units, so that can exercise the quality of students to bear hardships and stand hard work, to cultivate students' pragmatic spirit, but it's important to note that college students must be in before graduation practice, organize students to participate in business training in teaching activities, and graduation practice for students business plan, so as to further improve the students' creative ability.

\subsection{Innovation entrepreneurship practice platform provides colleges and universities.}

\subsubsection{To create a platform for innovation.}

Colleges and universities should promote resource sharing, to save the concept of environmental protection, especially can create innovative entrepreneurial platform for the students on campus of colleges and universities, colleges and universities can be existing experimental sites, such as laboratory equipment as the foundation, according to the practical innovation entrepreneurship training basic practice type needs to scale, structure, such as planning and deployment, the best use of laboratory equipment to dig more experimental function [6]. In addition, colleges and universities can provide students with open laboratory, in does not affect the normal teaching work, let the student practice of innovative entrepreneurial project training and practice, as a result, the laboratory can play a role in cultivating students' innovative undertaking quality not only, also is helpful for students' exploratory learning and research.

\subsubsection{Do a good job in the construction of campus entrepreneurship.}

The campus venture investment main body are generally government, business, etc. , it is an important part of Chinese education system in colleges and universities, the construction of campus entrepreneurial usually will entrepreneurship practice, entrepreneurship training, entrepreneurship services together, as a result, not only can promote the combination between teaching and research in colleges and universities, and conducive to the cultivation of university students' innovative thinking [7]. Colleges and universities to establish the campus entrepreneurial activity requires the professional characteristics, especially to encourage students to gradually into the laboratory research base to do further research and development, and can through legal and financial early to avoid the risk of entrepreneurship. In addition, the training of university teaching can make use of their own creative capabilities; hold some lectures on campus, and to cultivate the students' innovation ability, can improve the students' entrepreneurial skills.

\subsubsection{Enhancing university-enterprise cooperation.}

Off-campus practice base as students study in school, important place out of the school practice, students can through the trainee, internships to improve their professional skills, professional ethics accomplishment, the innovation ability, students can fully experience the social unit in the process of practice operation, workflow, management mechanism, etc., to help students entrepreneurship practice experience [7]. In addition, the combination of colleges and universities must attach importance to and off-campus practice base, particularly to take advantage of scientific research in colleges and universities, and overcome technical difficulties together, give full play to the creative education practice.

\subsection{Money guarantee of innovative entrepreneurial practice.}

Chinese university innovation entrepreneurship education practice work if you want to get a long-term development, you will need to get affordable college innovation entrepreneurship practice, 
innovation in colleges and universities entrepreneurship education belongs to the long-term strategic development goals, is investing in the future, the benefit to the students career, in particular about economic benefits of the social environment, it is hard to get attention by the department of education in colleges and universities, therefore, the creative work of colleges and universities should practice task, in the superior departments began to organize students to participate in practice [8]. In addition, due to the lack of systematic planning university innovation entrepreneurship is easy to appear the phenomenon of money does not reach the designated position, but the university students' innovative undertaking must have sufficient funds to start, so colleges must through various channels to ensure students entrepreneurial practice capital investment. In addition, the university innovation entrepreneurship to systemic project, the construction of the development of the practice, the practice base, the education and training of teachers and students, and so on all need to have corresponding money to guarantee, so the department of education leadership can be tailor-made for its financial policy, and innovative business practices to create special funds for colleges and universities, colleges and universities so that the leadership attaches great importance to the work of innovative entrepreneurial practice.

\section{Summary}

Innovation entrepreneurship education must face all student, the professional education into the whole process of personnel training, to change education idea, renewing education concept as the guide, in order to enhance the students' social responsibility, innovation, entrepreneurial spirit and entrepreneurial ability as the core, to reform the personnel training mode and curriculum system as the key point, constantly improve the quality of personnel training. Innovation, entrepreneurship education is not equal to create enterprise education, it not only teach knowledge about business, more important is to let students learn to think like entrepreneurs. Entrepreneurship education, vigorously promote innovation is to improve the independent innovation ability, the construction of an innovative country strategy, is to deepen reform of education teaching, cultivating students' innovative spirit and practice ability the important way, is to carry out the job creation and encourage entrepreneurship to create more employment opportunities, promote full employment of the important measures of higher vocational graduates.

\section{Acknowledgement}

Fund Project: This paper is one of the outcomes of the research, Fusion Research of Innovation a nd Entrepreneurship Education in Colleges and Universities and Smart City 2.0 Construction in Hen an Province, which is supported by the Foundation for Soft Sciences Planning Projects of Henan Pr ovince in 2018. Yanqiu Liang is the director of this project.

\section{References}

[1] H.B. Li, Promote the innovation in colleges and universities entrepreneurship education policy Suggestions, Science and technology, 2014, vol.5, pp. 226-229.

[2] H.T. Xue, Thinking about innovation in colleges and universities entrepreneurship education system, Higher education in Jiangsu province, 2014, vol.3, pp. 65-66.

[3] C.Y. Wang, The Chinese university innovation entrepreneurship education philosophy thinking, Guangdong academy of social sciences, 2013, vol.1, pp. 112-117.

[5] X.H. Huang, Mechanism analysis of the practice teaching of the college innovation entrepreneurship education, Higher education research in Heilongjiang province, 2015, vol. 11, pp. 122-124.

[6] Y.N. Wang, Innovative entrepreneurship education into the professional teaching, University teaching in China, 2015, vol.4, pp. 4-7. 
[7] J.T. Song, The research and practice of creative education pattern in colleges and universities under the new situation, Xingtai vocational and technical college journal, 2015, vol.2, pp.55-56.

[8] Q.X. Sun, Innovation in colleges and universities entrepreneurship education with professional education and practice, The significance of innovation and entrepreneurship education, 2013, vol.4, pp.49-51. 